\title{
Beyond GDP: Measuring What Counts for Economic and Social Performance
}

PRIKAZ KNJIGE

DOI: https://doi.org/10.15179/pkiep.27.2.3

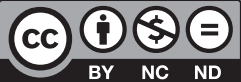

Joseph Stiglitz, Jean-Paul Fitoussi i Martine Durand

Pariz: OECD Publishing, 2018, 143 str.

\section{Ivo Bićanić*}

U svijetu konja galoperi su uzgojeni za galopiranje, kasači za kasanje, preponaši za skakanje, i tako dalje. Ne dobiju se dobri rezultati ako se galoperi koriste u kasačkim trkama. O tome govori ova knjiga. BDP je osmišljen za jedno, a koristi se za nešto drugo. Za to drugo treba izraditi novi pokazatelj i time se bavi najvažniji i najveći dio knjige.

Nakon Drugog svjetskog rata UN je izradio (točnije, Simon Kuznets i Richard Stone, za što su, među inim, dobili Nobelovu nagradu, prvi 1971., a drugi 1984.) sustav nacionalnih (društvenih) računa čiji je cilj bio omogućiti primjenu kejnzijanskih ekonomskih politika pune zaposlenosti i peglanja ciklusa. Osnovna makroekonomska mjera društvenih računa bio je bruto domaći proizvod (BDP). Ta je mjera kreirana za mjerenje razine ekonomske aktivnosti narodnog gospodarstva. No došlo je do pomaka: "BDP je bio izgrađen i korišten za mjerenje tržišnih aktivnosti, no sve više je postajao termometar korišten za procjenu općeg zdravlja društva" (str. 19). Posljedice korištenja BDP-a za nešto čemu nije namijenjen bile su nedopustive greške

\footnotetext{
` Ivo Bićanić, redoviti profesor u mirovini, Sveučilište u Zagrebu.
} 
u procjeni stanja i shodno tome u izboru mjera za njegovo poboljšanje. Rezultat su nepotrebni društveni troškovi i neefikasnost.

Problem nije nov. Od samog početka, dakle već od pedesetih godina, Kuznets je bio svjestan ograničenja BDP-a. Iz njegovih radova posve je jasno da je bio svjestan opasnosti, površnosti i grešaka koje proizlaze ako se BDP koristi za svrhe kojima nije namijenjen. Naravno, toga su bili svjesni i drugi ekonomisti te je literatura o ograničenjima i neprimjerenosti BDP-a za razne namjene cvala i još raste.

Među isticanim nedostacima BDP-a osobito je bila na meti greška koja slijedi ako se BDP koristi na bilo koji način kao neka mjera rasta, uspješnosti gospodarskog procesa ili dobrobiti (u knjizi se namjerno ne koristi pojam blagostanje, nego "well-being"). Međutim, ekonomiste, a i javnost je zanimalo kako doći do dobrog pokazatelja dobrobiti pa su uloženi napori da se izgradi prikladna mjera uspješnosti, rasta i dobrobiti. Ti napori išli su u tri smjera: bolje računanje BDP-a, sastavljanje kompozitnih indeksa i izgradnja "nadzorne ploče" (table s utvrđenim pokazateljima, "dashboard"). Kompozitnim indeksima se knjiga ne bavi, što je razumljivo jer ozbiljni ekonomisti o njima nemaju dobro mišljenje. Ona se bavi prikazom ograničenja i grešaka koje izaziva ovisnost o BDP-u, a središnja i glavna tema je izgradnja nadzorne ploče koja daje uvid u stvarno stanje gospodarstva i njegove dobrobiti.

Što ne valja s BDP-om? Time se na nekoliko mjesta autori bave, ali najviše na početku, u prvom poglavlju pod nazivom Važnost nastavka programa "napuštanja BDP-a". Većinu tehničkih zamjerki statističari su uklonili ili doveli u prihvatljive okvire. "Temelini problemi se javljaju čim se odmakne od jednostavnog modela... značajne aktivnosti su izvan tržišta... na dobrobit utječu drugi faktori... postoje mnogi tržišni neuspjesi... [za ocjenu stanja] važna je održivost... na koncu, kao društvo, možemo se brinuti o raspodjeli dobrobiti... Postoji dakle više razloga zašto BDP nije dobra mjera društvenog blagostanja" (str. 24-25). No taj pomak ima posljedice jer vrijedi Stiglitzova krilatica: "Što mjeriš utječe na to što radiš" (str. 2) ili "naše mjerenje ima posljedice" (str. 20), koja se u varijacijama nekoliko puta ponavlja u knjizi. 
Knjiga počinje time kako je taj pomak utjecao na neprepoznavanje dolaska krize i kasnije na krive reakcije na Veliku recesiju 2008. Postojali su podaci o pravom stanju, "ali nisu bili dio ustrojenog sustava praćenja pa su ih zanemarili oni koji su ih trebali primijetiti" (str. 20). Kriva procjena stanja vodila je krivim politikama. To je jedna od važnih tema knjige i za nju se navode primjeri.

Ideju formalizirane nadzorne ploče prvo je predložila Stiglitz-Sen-Fitoussi komisija (Commission on the Measurement of Economic Performance and Social Progress) koja je objavila svoj vrlo opsežan izvještaj 2009. Ta je komisija osnovana na inicijativu ondašnjeg francuskog predsjednika Nicholasa Sarkozyja kojeg je kao političara jako brinuo "jaz između 'stručnjaka' i građana kojima bi oni trebali služiti, [a koji je] imao veliku ulogu u [nastanku] oštrih podjela unutar društva, koje su bile tako vidljive u nizu nedavnih izbora" (str. 19). Kao posljedica je "većina zemalja OECD-a danas suočena s 'krizom povjerenja'”' (str. 21). Zbog toga se činilo da su "agregatni ekonomski pokazatelji, kao što je BDP, u neslozi sa 'stanjem na terenu'"' (str. 20). Stiglitz-Fitoussi-Durand komisija (High-Level Group on the Measurement of Economic Performance and Social Progress, HLEG), čiji je rad temelj ove knjige, nastavila je rad Stiglitz-Sen-Fitoussi komisije (Amartya Sen se iz objektivnih osobnih razloga povukao, a priključila se glavna statističarka OECD-a Martine Durand). To je bilo potrebno jer je prva komisija završila s radom prije Velike recesije pa njene pouke nisu bile uključene u zaključke i jer je "trebalo ocijeniti postignuto, usmjeriti i održati dinamiku [promjena] i prepoznati nova područja koja zahtijevaju dodatni rad" (str. 60). Rad HLEG-a nastavljen je pod patronatom OECD-a i oko osnovne ideje utemeljeno je nekoliko projekata koje je financirao OECD i čiji su rezultati dostupni javnosti.

Rad HLEG-a nije predstavljen kao onaj prethodne komisije, nego su 2018. objavljeni posebno sažetak i posebno zbirka poglavlja sudionika projekta. Knjiga koja se ovdje prikazuje je sažetak koji su napisali voditelji projekta, Joseph Stiglitz (sa Sveučilišta Columbia, dobitnik Nobelove nagrade 2001. godine), Jean-Paul Fitoussi (sa Sveučilišta Sciences-Po u Parizu i Sveučilišta Luiss u Rimu) i Martine Durand (glavna statističarka OECD-a). Ovo 
je kratka knjižica, sastavljena od 119 stranica podijeljenih u samo pet poglavlja s dodatkom i opsežnom bibliografijom, ali je bogata sadržajem. To je razumljivo jer sažima desetljeće rada mnogih istraživača okupljenih u dva projekta. Kao što autori kažu, ovo nije uobičajeni sažetak, nego osobno svjedočanstvo voditelja: "Ova knjiga predstavlja naše viđenje rasprava..." (str. 3); oni tu ne predstavljaju mišljenje grupe, nego svoje tumačenje raspravljanih tema.

Rješenje koje nudi Stiglitz-Sen-Fitoussi komisija i naglašava njena nasljednica Stiglitz-Fitoussi-Durand komisija je "napuštanje pretjerane ovisnosti o BDP-u kada procjenjujemo zdravlje zemlje [u korist] šire nadzorne ploče pokazatelja... izazov je da nadzorna ploča bude dovoljno mala da bude razumljiva, ali dovoljno velika da uključi sažetak onoga do čega nam je najviše stalo" (str. 22-23). Sastaviti takvu nadzornu ploču nije jednostavno jer postoje nacionalni prioriteti, a još teže je napraviti ploču koja je međunarodno usporediva. To ostaje zadatak za budućnost, ova knjiga samo pokazuje da je to zadatak koji treba obaviti i upućuje na korisne smjerove kojima bi razrada trebala ići (u dodatku daje i moguću strukturu nadzorne ploče).

Početak prvog poglavlja je posvećen opisanom, a ostatak se bavi ključnim promjenama zbog kojih se nadzorna ploča gradi. "Velika recesija imala je dvije posljedice: rast ekonomske nesigurnosti i podrivanje povjerenja ljudi, posebno u javne institucije" (str. 28). "Istovremeno je rastuća zabrinutost o rastu nejednakosti i globalnom zatopljenju stavila još veći naglasak na održivost u svim njezinim dimenzijama" (str. 28). Dolazi i do strukturnih promjena koje BDP slabo bilježi i prati. Mnoge ekonomske aktivnosti prelaze iz kućanstva na tržište, slabi država blagostanja, mirovinski sustavi se mijenjaju, stambena pitanja postaju sve važnija, raste broj usluga i proizvoda koje nudi vlada, javlja se digitalna ekonomija, rastu inovacije i BDP sve to ne mjeri dobro i ne uvažava dovoljno.

Poglavlje završava s dva primjera koji pokazuju kako "distorzije mjerenja mogu biti pogubne" (str. 33). Prvi primjer tiče se okoliša i kako njegovo uništavanje može pozitivnu stopu rasta BDP-a pretvoriti u pad. Drugi je 
vezan uz privatizaciju društvene sigurnosti, kada rast BDP-a može pratiti rast nesigurnosti koji ga neutralizira.

Drugo poglavlje Mjerenje gospodarskog pada je kratko i bit će posebno zanimljivo hrvatskim čitateljima jer se bavi mjerenjem ekonomskih kontrakcija. Tri stvari treba istaknuti. Prvo, "da smo imali bolje pokazatelje... mogli smo shvatiti da je pad dublji nego što su ukazivale statistike BDP-a" (str. 41). Drugo, da je bila poznata dubina pada, "možda bi vlade odgovorile snažnije s ciljem ublažavanja negativnih učinaka krize" (str. 41). Treće, "gospodarstva koja dožive velike padove možda se nikada ne oporave" (str. 47).

Možda je najveći uzrok lošeg zaključivanja na temelju BDP-a to što on zanemaruje promjene kapitala do kojih dolazi tijekom gospodarskog pada, odnosno krize. Taj je gubitak, koji predstavlja "destrukciju 'skrivenog bogatstva'" (str. 53), velik i utječe na ishode. On je posljedica smanjenih investicija i posljedičnog tehnološkog zaostajanja, ali i destrukcije ljudskog kapitala i znanja, zdravlja, društvenog kapitala i naročito povjerenja u institucije. Standardne statistike u bilancu kapitala ne uključuju te promjene. Osim zanemarivanja promjena kapitala, tu su i važne promjene na tržištu rada koje nisu bilježene (obeshrabreni radnici, bolovanja i invaliditet, izgubljeno obrazovanje, formalno i na radnom mjestu, skraćeno radno vrijeme i posebno pogođene grupe kao što su mladi, manjine, žene i slično), pri čemu "šire mjerenje nezaposlenosti... pokazuje mnogo višu razinu neiskorištenih radnih sposobnosti" (str. 51). Te posljedice gospodarskog pada vode do trajnih promjena. Usredotočenost samo na BDP ima i druge važne nepovoljne posljedice. Ističe se ekonomska sigurnost i subjektivni osjećaj dobrobiti, a što pad traje dulje, to više košta izgubljena ekonomska sigurnost.

No u pogledu tog zabilježenog gubitka autori zaključuju da "smanjenje stvarnog bogatstva zemlje... podriva ekonomski potencijal za budućnost. Gospodarstva koja dožive velike padove možda se nikada ne oporave" (str. 47). Naglašavaju razliku standardne teorije rasta koja ne prepoznaje utjecaj pada na dugoročnu stopu jer je ona egzogeno određena tehničkim 
napretkom, a utjecaj koji ima skriveni gubitak kapitala trajno usporava dugoročnu stopu. Stiglitz, Fitoussi i Durand pokazuju da dug i velik gospodarski pad utječe na dugoročnu stopu rasta i zato se ekonomije ne oporavljaju.

Ovo poglavlje daje autorima priliku da se obruše na posljedice koje ima kriva metrika, odnosno koje su uzrokovane krivim mjerenjem. Dokazuju da ta greška ima za posljedicu odabiranje pogrešnih mjera oporavka te su spriječeni automatski stabilizatori, a gledanje samo jedne strane bilance, tj. one koja ima dugovanja, spriječilo je primjenu efikasnih politika. Stoga upozoravaju da ne treba gledati samo jednu stranu bilance, odnosno dugove države niti bilancu države, nego bilancu narodnog gospodarstva, a "malo vlada sastavlja tu opću bilancu vlade i narodnog gospodarstva" (str. 49). Sveukupno gledajući, zbog krive metrike se na krizu krivo reagiralo i pad je dulje trajao.

No rad komisija (i knjiga koja ga sažima) ne bi imao puno smisla da samo pokazuje da BDP nije pouzdan. Cilj autora je ponuditi rješenje i to rade u drugoj polovici knjige, odnosno u zadnja tri poglavlja i dodatku.

Početak "aktivističkog" dijela knjige je treće poglavlje, Nastavak rada na zaključcima Stiglitz-Sen-Fitoussi komisije. To je najdulje poglavlje. U njemu Stiglitz-Fitoussi-Durand komisija predlaže devet područja za daljnji rad koja nakon Velike recesije moraju biti središnji dio nadzorne ploče. Svako od tih područja obrađeno je u jednom odjeljku poglavlja na sličan način: nakon opravdanja izbora nudi se metrika, a potom se navode implikacije za politiku.

Prvi predloženi skup pokazatelja izveden je iz Ciljeva održivog razvoja (Sustainable Development Goals) UN-a (ti su ciljevi nasljednici milenijskih razvojnih ciljeva UN-a, Millennium Development Goals). Taj dokument ima 169 ciljeva i 232 pokazatelja. To je previše pa im se broj mora smanjiti. "S obzirom na različite okolnosti u različitim zemljama, prirodno je da [ciljevi i pokazatelji] budu različiti i trebaju se usredotočiti na različite ciljeve... Razlike će biti osobito značajne između razvijenih i zemalja u 
razvoju" (str. 61). No s razlikama ne treba pretjerati jer "zemlje moraju biti svjesne prednosti usporedivosti" (str. 61).

Drugo područje od interesa odnosi se na ekonomske nejednakosti do kojih je Stiglitz-Fitoussi-Durand komisiji osobito stalo jer je "18 od 23 države OECD-a doživjelo značajno povećanje nejednakosti dohodaka" (str. 63), a BDP uopće ne uzima u obzir raspodjelu. Važnost nejednakosti u poglavlju autori dalje razrađuju s posebnim naglaskom na metriku (nemaju dobro mišljenje o Giniju) i podatke. Zaključuju da "treba prisiliti nositelje politike da procijene i koristi svojih odluka i troškove. Trebalo bi biti uobičajeno da se za svaku važnu političku odluku procijene njezine posljedice na raspodjelu, kao što je MMF počeo raditi" (str. 69-70).

Treće područje na nadzornoj ploči tiče se odnosa između makrostatistike i mikrostatistike o ekonomskim resursima kućanstava. Ekonomska politika je makroekonomska i u njezinom oblikovanju se vidi nepoznavanje utjecaja makropolitika na mikroodnose. Mada nije prepoznat, taj utjecaj postoji i važan je, pa je "očito važna usklađenost na makrorazini i mikrorazini" (str. 70). Slijede primjeri važnosti i posljedica zanemarivanja tog sklada.

Posebnu skupinu čine horizontalne nejednakosti. One "opisuju razlike između pojedinaca i grupa uvelike sličnog položaja, na primjer muškaraca i žena, različitih rasa ili etničkih skupina, ili unutar obitelji. Horizontalne nejednakosti su često povezane s diskriminacijom" (str. 71). StiglitzFitoussi-Durand komisija navodi kako je to zbog krvave povijesti posebno delikatno i zanemareno pitanje u Europi te ukazuje na neprihvatljivost zanemarivanja utjecaja ekonomskih politika na horizontalne nejednakosti. Peta tema su nejednake mogućnosti. "Ljudima je stalo do jednakih mogućnosti jer su [nejednakosti] nepravedne, neefikasne ili zbog oba razloga... nejednake mogućnosti vode ponavljanju nejednakih ishoda" (str. 73). Autori pokazuju kako se nejednake mogućnosti prelijevaju ne samo na dohodak nego i na zdravlje i na očekivanja za dug i zdrav život. Odjeljak posebnu pažnju posvećuje "spolu - koji ostaje ključna odrednica ishoda" (str. 75). 
Šesto se područje odnosi na subjektivni osjećaj dobrobiti. Važnost tog osjećaja pokazuje to što "otkad je OECD objavio Upute za mjerenje subjektivne dobrobiti (Guidelines on Measuring Subjective Well-Being) provedbu je prihvatila većina statističkih ureda zemalja članica OECD-a" (str. 77). Ovaj je osjećaj širi od Easterlinovog paradoksa iz sedamdesetih (koji pokazuje da nakon neke granice povećanje dohotka ne vodi povećanju subjektivnog osjećaja dobrobiti) jer je subjektivni osjećaj dobrobiti višedimenzionalan i ne može se svesti samo na dohodak.

Nakon Velike recesije istraživači su postali posebno svjesni važnosti ekonomske nesigurnosti jer je "ekonomska nesigurnost vrlo važan aspekt dobrobiti ljudi... ovdje se usredotočujemo na ekonomsku sigurnost, no granica između ekonomske sigurnosti i drugih oblika sigurnosti je nejasna" (str. 81). Dok ekonomsku nesigurnost smanjuje niz rješenja za osiguranje rizika koje nude osiguravajuće kuće, a ta rješenja ipak jesu tržišni neuspieh jer ne daju potpunu zaštitu, niz stvari je povećava, kao npr. smanjenje države blagostanja, ali i rast nejednakosti. Zbirni učinak je da se nesigurnost povećava iz niza razloga, tako da je "ekonomska nesigurnost izvor napetosti i bijede širom svijeta" (str. 83). No ekonomska nesigurnost raste i zbog nejednakosti i promjena na tržištu rada, ali i "jer su pojedinci osjetljiviji na gubitak dohotka nego na njegovo jednako veliko povećanje" (str. 83).

Predzadnja tema koja se razrađuje je održivost. Ekonomska održivost je uvelike vezana uz okoliš, zagađenje i međugeneracijsku pravdu. "Rast BDP-a danas nauštrb budućih generacija je neprihvatljiv... [jer] dobrobit se može danas povećati na račun smanjenja kapitala ključnog za održavanje buduće proizvodnje i dobrobiti" (str. 87). U ovom pogledu "očiti nedostatak tržišnih cijena naveo je komisiju da predloži da nadzorna ploča uključi i fizičke pokazatelje" (str. 88). Uz održivost su vezane ranjivost i otpornost.

Zadnja dimenzija koju autori uključuju je društveni kapital, a StiglitzFitoussi-Durand komisija "odlučila se usredotočiti na samo jedan vid društvenog kapitala, doduše vrlo važan, a to je povjerenje" (str. 93). "Kriza 2008. ne može se svesti samo na ekonomsku sigurnost, nego i na povjerenje. 
To je tako zbog općeg uvjerenja o nepravednosti načina na koji je rješavana" (str. 93). "Na povjerenje treba gledati kao na imovinu koja je ključni dio društvenog kapitala. Povjerenje dugo nastaje, ali može prilično brzo nestati" (str. 93). Autori posebno naglašavaju važnost povjerenja za funkcioniranje tržišnog gospodarstva, a primjećuju da "povjerenje i neformalna pravila koja oblikuju društvenu suradnju mogu objasniti razlike u gospodarskom razvoju" (str. 95).

Nema nikakve sumnje da je ova knjiga "aktivistička". Cilj Stiglitz-FitoussiDurand komisije je uvjeriti čitatelja u tri stvari. Prvo, da je potrebna nadzorna ploča za ocjenu pravog stanja gospodarstva. Drugo, da je politika utemeljena na takvoj nadzornoj ploči bolja od one koja koristi BDP. Treće, da je sastavljanje nadzorne ploče ostvariv i provediv cilj. "Veliki" je zaključak knjige (i rada komisije) da su ishodi mogli biti bolji da se nije sve temeljilo na BDP-u. Stoga je posve prirodno da su zadnja dva poglavlja i dodatak posvećeni aktivizmu.

Četvrto poglavlje, Iskustva zemalja s upotrebom pokazatelja dobrobiti kao usmjeritelja politike, ima u središtu nekoliko stvari. Prva je "šalabahter" postupaka potrebnih za razradu politike temeljene na dobrobiti. "Ovo poglavlje ispituje što se postiže kada se politici pristupa sa stajališta dobrobiti" (str. 104). Nude se postupci i potrebni koraci za povećanje svijesti o mjerenju dobrobiti i za uključivanje nadzorne ploče u službene statistike. Drugo, opisuju se iskustva zemalja koje su prihvatile neki oblik pokazatelja dobrobiti. Navedena su iskustva deset zemalja: Australije, Ekvadora, Francuske, Italije, Nizozemske, Novog Zelanda, Škotske, Švedske, Ujedinjenih Arapskih Emirata i Ujedinjenog Kraljevstva, a u dodatku su dodane Njemačka i Izrael. "Nekoliko zemalja OECD-a razvilo je formalni i/ili strukturirani mehanizam koji osigurava primjenu pokazatelja dobrobiti, odnosno pokazatelja 's onu stranu BDP-a'”' (str. 106). To znači da postoje iskustva kako je nadzorna ploča postala dio službenog redovitog rada statističkih službi, ministarstava i analitičara. Zanimljivo je da su autori i sami začuđeni tim širokim prihvaćanjem pristupa koji zagovaraju. U dodatku dalje razrađuju šprancu, iskustva i algoritam provedbe, do te mjere da preporučuju pokazatelje koje treba imati na nadzornoj ploči. No 
autori su svjesni velikog problema: "Ključni izazov je mogu li inicijative koje je prihvatila jedna vlada preživjeti izbor sljedeće vlade, naročito ako potonju sastavlja druga stranka ili koalicija" (str. 111).

Peto i zadnje poglavlje, Dvanaest preporuka za put razvoja mjerenja dobrobiti, je najkraće. Za sastavljanje nadzorne ploče Stiglitz-FitoussiDurand komisija navodi 12 preporuka (str. 117-118):

1. Jedan pokazatelj ne može biti dobra mjera. Nadzorna ploča mora uključivati pokazatelje koji omogućuju procjenu uvjeta življenja ljudi tijekom gospodarskog ciklusa.

2. Važnost razvijanja boljih pokazatelja dobrobiti ljudi vrijedi za sve zemlje bez obzira na stupanj razvoja.

3. Kakvoću i usporedivost postojećih pokazatelja ekonomskih nejednakosti treba dalje unaprijediti.

4. Pokazatelji trebaju biti dezagregirani prema dobi, spolu, ranjivosti, spolnoj orijentaciji, obrazovanju i drugim obilježjima tržišnog i društvenog statusa.

5. Treba stremiti integraciji informacija o ekonomskim nejednakostima $\mathrm{u}$ sustavu nacionalnih računa s ciljem konvergencije različitih pristupa na mikrorazini i makrorazini.

6. Procjena jednakih mogućnosti je važna.

7. Mora se provoditi redovito, često i standardizirano prikupljanje i ocjena podataka o iskustvima i mjerama subjektivne dobrobiti.

8. Redovito treba ocijeniti utjecaj politika na ekonomsku sigurnost ljudi koja je mjerena pokazateljima na nadzornoj ploči.

9. Potrebne su bolje mjere održivosti.

10. Mjere povjerenja i druge mjere društvenih norma treba unaprijediti.

11. Treba omogućiti pristup podacima i službenim izvorima.

12. Za postizanje "boljih politika za bolje živote" treba koristiti pokazatelje dobrobiti kod donošenja odluka u svim fazama procesa.

Na kraju treba naglasiti da je Stiglitz-Fitoussi-Durand komisija svjesna važnosti odnosa svojih prijedloga i rasta BDP-a. Njezin je odgovor dvojak. Prvo, rast BDP-a i dobrobiti ne moraju se poklapati, no jedino mjerenje 
dobrobiti može odrediti veličinu i postojanje "dobrog rasta" i "inkluzivnog rasta". Međutim, nema nužno sukoba jer "rast BDP-a može biti potreban da se proizvedu resursi potrebni za jačanje dobrobiti" (str. 112). Drugo, u konačnici rast dobrobiti vodi do rasta BDP-a; dakle, u duljem roku nema sukoba pa usredotočenost na dobrobit ne znači manji dugoročni rast.

Cilj ove knjige, i rada komisija na kojem se temelji, je uvjeriti struku (ekonomsku i statističku), javnu upravu, širu javnost i političare da BDP nije dobra mjera za ocjenu dobrobiti društva i da ga treba zamijeniti "nadzornom pločom" sastavljenom od niza pokazatelja. U dodatku autori predlažu i moguću strukturu takve ploče, ali naglašavaju da svaka zemlja gradi svoju, uz poštovanje međunarodne usporedivosti.

Mali broj zemalja počeo je izrađivati i službeno koristiti svoju nadzornu ploču, uglavnom za ograničene ciljeve. Hrvatska nije među njima: BDP caruje i nema prijedloga za izgled neke službene nadzorne ploče, niti se na njoj radi. Ograničenja BDP-a su dugo poznata i manji broj ekonomista na to upozorava te izražava nezadovoljstvo načinom kako se koristi BDP kao osnovna mjera za ocjenu uspješnosti gospodarstva. To nezadovoljstvo nije počelo ovom knjigom, ali ona može značajno doprinijeti rastu svijesti o ideji promjene. Autoritet voditelja i članova komisija ulijeva nadu u mogući pomak. Sada se u Hrvatskoj povremeno nude složeniji pokazatelji dobrobiti koji su prikupljeni ad hoc. No dalje se nije otišlo; nemamo prijedlog izgleda nadzorne ploče i statistička služba i javna uprava nisu se pomakle u smjeru sastavljanja neke nadzorne ploče. Javnost i političari još uvijek su čvrsto ukotvljeni u korištenju BDP-a, i ako išta, ta se praksa samo učvršćuje. Kako izgleda, takvo će stanje potrajati, što može dovesti do donošenja odluka koje nisu najbolje i koje ne bi bile donesene da se raspolaže nadzornom pločom kakvu zagovaraju u ovoj knjizi Stiglitz, Fitoussi i Durand. 